\title{
Permeability of milk protein antigens across the intestinal epithelium in vitro
}

\author{
D. Marcon-Genty, D. Tomé * A.M. Dumontier, O. Kheroua and \\ J.F. Desjeux
}

INSERM U 290, fonctions intestinales, métabolisme et nutrition, hôpital Saint-Lazare, 107, rue du Faubourg St-Denis, 75010 Paris, France

(14th meeting of the INRA Development Group, Clermont-Ferrand, 25-27 May 1988)

Summary - Degradations by proteolytic enzymes and intestinal epithelial permeability represent two major drawbacks to the transfer of food protein antigens to blood. These steps were studied in vitro for the milk protein antigens $\beta$-Lactoglobulin $(\beta-L g), \alpha$-Lactalbumin $(\alpha-L a)$ and $\beta$-casein ( $\beta$-cas). Pepsin-trypsin hydrolysis and permeability in isolated rabbit ileum in Ussing chamber were suited by ELISA and radiolabelled-protein measurement. Pepsin-trypsin hydrolysis showed an increasing resistance in the order $\beta$-cas $<\alpha$-La $<\beta$-Lg. The rate of absorption of the antigenic proteins by isolated rabbit ileum was in the same order, and the rate of absorption of the whole proteins (degraded and antigenic forms) was significantly higher for $\beta$ - $\mathrm{Lg}$ than for $\alpha$-La and $\beta$-cas. These results suggest a selective intestinal permeability for milk protein antigens. This selectivity is probably important in the mechanism of food protein sensitization via the oral route.

absorption - intestine $-\beta$-Lactoglobulin $-\alpha$-Lactalbumin - caseins

Résumé - Absorption intestinale In vitro des protéines de lalt. La digestion par les protéases intraluminales et la perméabilité de l'épithélium intestinal représentent deux étapes limitantes majeures pour le transfert d'antigènes protéiques alimentaires vers le sang. Ces étapes ont été étudiées in vitro dans le cas de la $\beta$-Lactoglobuline $(\beta$-Lg), l' $\alpha$-Lactalbumine $(\alpha$-La), et la $\beta$-caséine $(\beta$-cas) du lait de vache. L'hydrolyse successive pepsine-trypsine, et la perméabilité à travers liléon de lapin isolé en chambre de Ussing, ont été suivies par dosage ELISA et par mesure radioisotopique. L'hydrolyse pepsine-trypsine indique une résistance croissante dans l'ordre $\beta$-cas $<\alpha$-La $<\beta$ - Lg. Les vitesses d'absorption des protéines sous forme antigénique se rangent dans le même ordre, et la vitesse d'absorption totale (forme antigénique et dégradée) est significativement plus élevée pour la $\beta$-Lg que pour l' $\alpha$-La et la $\beta$-cas. Ces résultats suggèrent une perméabilité sélective de l'intestin pour les antigènes protéiques du lait. Cette sélectivité joue probablement un rôle important dans les mécanismes de sensibilisation par voie orale.

absorption - intestin - $\beta$-Lactoglobullne - $\alpha$-Lactalbumine - caséines

* Correspondence and reprints. 


\section{INTRODUCTION}

The mechanism inducing food protein sensitivity via the oral route is complex and still unclear (Patrick \& Gall, 1988). It is generally accepted that proteins or their antigenic fragments, which resist degradation by proteolytic enzymes of the gastrointestinal tract and cross the intestinal mucosa intact, are able to stimulate immunocomponent cells in the lamina propria (Baird et al., 1987; Fällström et al., 1984; Cornell et al., 1971; Heyman et al., 1982; Koritz et al., 1987; Stern \& Walker, 1984; Walker et al., 1972). For this reason, it is important to know the proportion of antigenic protein that remains present during digestion by gastrointestinal enzymes and during their intestinal transepithelial passage. For a study of this kind, milk protein antigens appeared to be a good model since they are known to induce anaphylactic sensitization in some subjects (Baird et al., 1987; Changin et al., 1981; Huang et al., 1985; Pearson et al., 1983; Suzuki et al., 1987) and are easily available in a pure form (Mercier et al., 1968).

In the present study, the bovine milk protein antigens $\beta$-Lactoglobulin $(\beta-\mathrm{Lg}), \alpha-$ Lactalbumin ( $\alpha$-La) and $\beta$-casein ( $\beta$-cas) were suited by immunoenzymatic assay (ELISA) or radiolabelled-protein measurement during pepsin-trypsin hydrolysis in vitro, and during their transepithelial passage through isolated rabbit ileum. The results showed that $\beta-\mathrm{Lg}$ antigens were more able to resist pepsin-trypsin degradation and to cross the intestinal mucosa.

\section{MATERIALS AND METHODS}

\section{Chemicals}

Bovine $\beta-\operatorname{Lg}$ and $\alpha$-La were of commercial origin (Sigma) and $\beta$-cas was purified from fresh milk
(Mercier et al., 1968). Proteins were ${ }^{14} \mathrm{C}$ radiolabelled by reductive alkylation of amino groups using ${ }^{14} \mathrm{C}$-formaldehyde (Jentoft \& Dearborn, 1979).

\section{Pepsin-trypsin hydrolysis}

Successive pepsin-trypsin (E/S - 1/100) hydrolysis of the proteins $(5 \mathrm{mg} / \mathrm{ml})$ was performed at $37^{\circ} \mathrm{C}$ at $\mathrm{pH} 2$ adjusted with $\mathrm{HCl}$ for pepsin, and in $0.02 \mathrm{M}$ sodium borate $\mathrm{pH} 8.2$ for trypsin. Aliquots ware collected at different times for free $\alpha$ amino group determination (Reimerdes \& Klostermeyer, 1976), and ELISA.

\section{Using chamber experiments (Powell et al., 1972)}

White, male, New Zealand rabbits weighing 2-3 $\mathrm{kg}$ were killed by intravenous pentobarbital sodium injection. Pieces of stripped distal ileum were mounted between the two halves of a Lucite chamber (exposed area $3.14 \mathrm{~cm}^{2}$ ) and bathed on each side at a temperature of $37^{\circ} \mathrm{C}$ by $12 \mathrm{ml}$ of isotonic Ringer solution containing (in $\mathrm{mM}$ ) $140 \mathrm{Na}^{+}, 5.2 \mathrm{~K}^{+}, 1.2 \mathrm{Ca}^{2+}, 1.2 \mathrm{Mg}^{2+}$, $120 \mathrm{Cl}^{-}, 25 \mathrm{HCO}_{\overline{3}}, 2.4 \mathrm{HPO}_{\overline{4}}^{2}, 0.4 \mathrm{H}_{2} \mathrm{PO}_{4}(\mathrm{pH}$ 7.4 with $95 \% \mathrm{O}_{2} 5 \% \mathrm{CO}_{2}$ ). The spontaneous transmucosal electrical potential difference (PD) was continuously short-circuited by a shortcircuit current (Isc) delivered by an automatic voltage clamp system (WPI, New Haven, CT, USA) that corrected for fluid resistance. The electrical conductance $(G)$ of the tissue was calculated according to Ohm's law. After $30 \mathrm{~min}$, ${ }^{14} \mathrm{C}$-proteins were added to the mucosal reservoir $(5 \mu \mathrm{Ci}, 1 \mathrm{mg} / \mathrm{ml})$. Aliquots were collected when necessary from the mucosal and serosal reservoir for radioactivity measurement and ELISA. After $140 \mathrm{~min}$, each reservoir was emptied and the corresponding solution adjusted to $12 \%$ trichloroacetic acid and centrifuged. The precipitate was used for HPLC analysis.

\section{Analytical techniques}

For the enzyme-linked immunosorbent assay (ELISA), Microtiter plates (Polylabo) were coat- 
ed overnight at $4^{\circ} \mathrm{C}$ with $100 \mu$ of samples adjusted to $\mathrm{pH} 9.6$ with $0.5 \mathrm{M}$ carbonate buffer. The plates were washed and incubated $1 \mathrm{~h}$ at $37^{\circ} \mathrm{C}$ with $1 \%$ gelatin; after washing, they were incubated $1 \mathrm{~h}$ at $37^{\circ} \mathrm{C}$ with $100 \mu \mathrm{l}$ of the appropriate rabbit antiserum (1/1000). Detection was performed with goat anti-rabbit lgG conjugated with horseradish peroxydase (Institut Pasteur, $1 / 3000$ ), and diaminoor thophenylene and $\mathrm{H}_{2} \mathrm{O}_{2}$ as substrates. The detection limit was $4 \mathrm{ng} / \mathrm{ml}$ for $\beta$ - $L g$ and $\alpha-L a$, and $15 \mathrm{ng} / \mathrm{ml}$ for $\beta$-cas. Highpressure liquid chromatography (HPLC) was performed with a Waters gradient system equipped with a C18 $\mu$-Bondapack column (350 $x 4.6 \mathrm{~mm}$ ), eluted at $40^{\circ} \mathrm{C}$ with a linear gradient of acetonitrile in $0.1 \%$ trifluoroacetic acid at a flow rate of $2 \mathrm{ml} / \mathrm{min}$ in $20 \mathrm{~min}$.

\section{Calculations}

Results were expressed as means \pm SE. Statistical analysis was performed using the paired or unpaired Student's $t$-test.

\section{RESULTS}

During pepsin-trypsin hydrolysis, $\beta$-cas released more free amino groups than $\alpha$-La, whereas, $\beta-\mathrm{Lg}$ was the least degraded (Fig. 1A). After pepsin treatment, no antigenic response was detected for $\beta$-cas, whereas, 0.2 and $12 \%$ of $\alpha$-La and $\beta$-Lg, respectively, continued to respond. The subsequent action of trypsin suppressed the antigenic reaction of $\alpha$-La, but $1 \%$ of the response of $\beta-\mathrm{Lg}$ was still detectable after $180 \mathrm{~min}$ (Fig. 1B).

${ }^{14} \mathrm{C}$-radiolabelled proteins were introduced on the mucosal side of rabbit ileum in an Ussing chamber (Table I). No effect was observed on the electrical parameters of the tissue. On the mucosal reservoir, the total radioactivity was not affected after
120 min of incubation, whereas, the antigenic response, that was not altered for $\beta$ - $L$ g and $\alpha$-La, was $20 \%$ reduced for $\beta$-cas after $120 \mathrm{~min}$, indicating a slight degradation of $\beta$-cas in the mucosal reservoir.

After the introduction of the labelled proteins on the mucosal side of rabbit ileum, the serosal accumulated radiolabelled material increased with time for the three proteins, the steady-state being reached only after a 60-70 min period (Fig. 2). For $\beta$-cas, the serosal antigenicity was never different from that measured in a control chamber without mucosal proteins, whereas, with $\beta$ $\mathrm{Lg}$ and $\alpha$-La, the antigenic response became significantly different from that of the

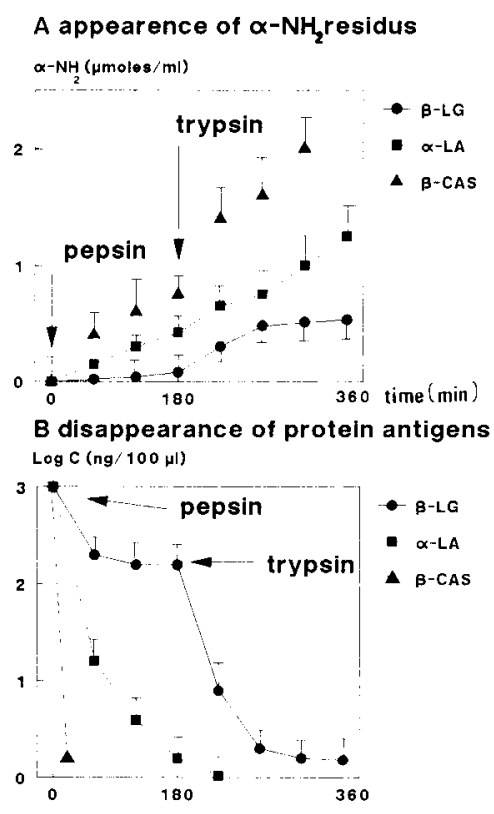

Fig. 1. Successive hydrolysis by pepsin and tryp$\sin$ of $\beta-\mathrm{Lg}, \alpha-\mathrm{La}$ and $\beta$-cas. A. Release of free $\alpha$ amino groups expressed in leucine equivalents $(\mu \mathrm{mols} / \mathrm{ml})$. B. Disappearance of antigenic determinants measured by ELISA and expressed in protein equivalents $(\mathrm{mg} / \mathrm{ml})$. Pepsin was introduced at $t=0$, and trypsin at $t=180 \mathrm{~min}$. Values are means \pm SE for 4 experiments. 
control chamber without mucosal proteins after $60 \mathrm{~min}$ and then linearly increased with time (Fig. 3). The rate of serosal accumulation of total radiolabelled material and antigenic proteins was then calculated in the $70-140 \mathrm{~min}$ period of incubation (Table II). The rate of total radiolabelled material accumulation was significantly higher with $\beta-\mathrm{Lg}$ than with $\alpha$-La and $\beta$-cas. The rate of

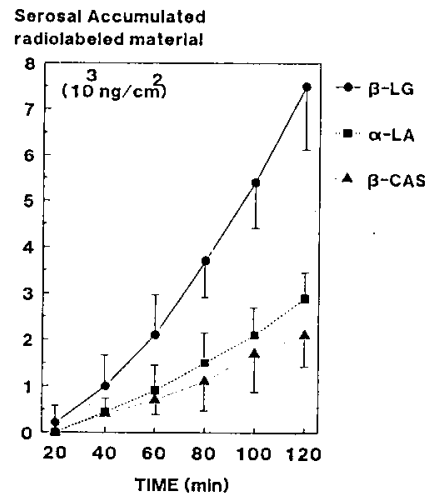

Flg. 2. Time-dependent accumulation of radioactivity on the serosal side of stripped rabbit ileum mounted in an Ussing chamber (exposed area $3.14 \mathrm{~cm}^{2}$ ), after the introduction into the mucosal reservoir of $1 \mathrm{mg} / \mathrm{ml}^{14} \mathrm{C}$-radiolabelled $\beta$-Lg, $\alpha$-La or $\beta$-cas. Results are expressed in $14 \mathrm{C}$-protein equivalents in $\mathrm{ng} / \mathrm{cm}^{2}$ of tissue. Values are means $\pm S E$ for 6 animals.

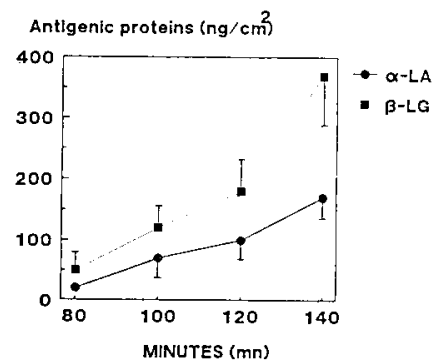

Fig. 3. Time dependent accumulation of antigenic determinants of $\alpha$-La and $\beta-\mathrm{Lg}$ in the serosal side of stripped rabbit ileum mounted in an Ussing chamber (exposed area $3.14 \mathrm{~cm}^{2}$ ), after the introduction into the mucosal reservoir of $1 \mathrm{mg} / \mathrm{ml}$ ${ }^{14} \mathrm{C}$-radiolabelled $\beta$ - $\mathrm{Lg}$ or $\alpha$-La. Results are expressed in antigenic proteins in $\mathrm{ng} / \mathrm{cm}^{2}$ of tissue. Values are means $\pm S E$ for 6 animals. antigenic protein accumulation was significantly higher with $\beta-\mathrm{Lg}$ than with $\alpha-\mathrm{La}$ and not detected for $\beta$-cas.

At the end of the 140 min period of incubation of $\beta-\mathrm{Lg}$ or $\alpha-\mathrm{La}$ on the mucosal side of rabbit ileum in vitro, the TCA-insoluble fraction of the serosal reservoir was analyzed by HPLC coupled with ELISA detection (Fig. 4). In each case, an antigenic response was detected exactly at the position of the intact proteins on the chromatogram.

\section{DISCUSSION}

Cow's milk proteins are of high nutritional quality, but are known to induce hypersensitive reactions in some subjects (Changin et al., 1981; Fällström et al., 1984; Pearson et al., 1983). These proteins consist of two fractions : a micellar casein fraction and a whey protein fraction. Bovine

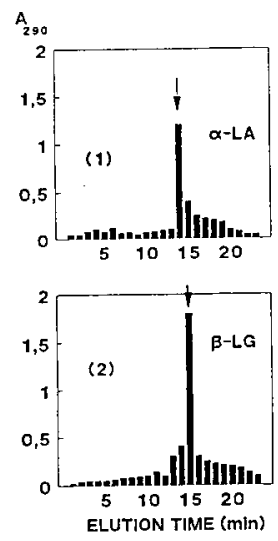

Fig. 4. Reverse-phase High Pressure Liquid Chromatography pattern with ELISA detection of the TCA-insoluble fraction of the serosal reservoir content of an Ussing chamber at time $140 \mathrm{~min}$ after introduction into the mucosal reservoir of 1 $\mathrm{mg} / \mathrm{ml} \alpha-\operatorname{La}(1)$ or $\beta-\operatorname{Lg}(2)$. 
Table I. Electrical parameters and mucosal concentration in $\beta-\mathrm{Lg}, \alpha$-La and $\beta$-cas, measured by ${ }^{14} \mathrm{C}$ counting or ELISA after introduction of $1 \mathrm{mg} / \mathrm{ml}{ }^{14} \mathrm{C}$-radiolabelled proteins, or Ringer only for control, in the mucosal side of rabbit ileum in an Ussing chamber.

\begin{tabular}{|c|c|c|c|c|c|c|}
\hline & & & Ringer & $\beta-L g$ & $\alpha-L a$ & $\beta$-cas \\
\hline $\begin{array}{l}\text { Electrical } \\
\text { Parameters }\end{array}$ & & $\begin{array}{l}\text { IsC } \\
P D \\
G\end{array}$ & $\begin{array}{l}35.6 \pm 4.7 \\
-2.3 \pm 0.3 \\
15.1 \pm 1.7\end{array}$ & $\begin{array}{r}36.2 \pm 6.8 \\
-2.3 \pm 0.4 \\
15.9 \pm 1.6\end{array}$ & $\begin{array}{r}32.4 \pm 2.5 \\
-2.3 \pm 0.2 \\
14.2 \pm 1.6\end{array}$ & $\begin{array}{r}42.7 \pm 4.5 \\
-2.4 \pm 0.2 \\
14.7 \pm 1.2\end{array}$ \\
\hline $\begin{array}{l}\text { Mucosal } \\
\text { proteins } \\
(\mathrm{mg} / \mathrm{ml})\end{array}$ & $\begin{array}{l}t=0 \min \\
t=120 \mathrm{~min}\end{array}$ & $\begin{array}{l}{ }^{14} \mathrm{C} \\
\text { ELISA } \\
{ }^{14} \mathrm{C} \\
\text { ELISA }\end{array}$ & $\begin{array}{l}- \\
- \\
-\end{array}$ & $\begin{array}{r}0.99 \\
\pm 0.05 \\
0.94 \\
\pm 0.09 \\
0.95 \\
\pm 0.06 \\
0.90 \\
\pm 0.10\end{array}$ & $\begin{array}{r}1.03 \\
\pm 0.04 \\
0.97 \\
\pm 0.11 \\
0.92 \\
\pm 0.08 \\
0.88 \\
\pm 0.09\end{array}$ & $\begin{array}{r}0.98 \\
\pm 0.05 \\
0.95 \\
\pm 0.09 \\
0.91 \\
\pm 0.09 \\
0.69 \\
\pm 0.09\end{array}$ \\
\hline
\end{tabular}

Values are means \pm SE for 8 animals. ${ }^{14} \mathrm{C}$-radiolabelled proteins $(1 \mathrm{mg} / \mathrm{ml})$, or Ringer only for control, were introduced in the mucosal reservoir at time 0 . Isc $\left(\mu \mathrm{A} / \mathrm{cm}^{2}\right), P D(\mathrm{mV})$ and $\mathrm{G}(\mathrm{m} 5 / \mathrm{cm})$ are mean values in the 60-120 min period. * significantly different, $P<0.01$. No significant difference was ever found for the electrical parameters.

casein is a mixture of the $\alpha s_{1}, \alpha s_{2}, \beta$ and $k$ caseins. The two major whey proteins are $\beta-\mathrm{Lg}$ and $\alpha$-La. Caseins are demonstrated to be rapidly degraded by proteolytic enzymes of the gastrointestinal tract (Jakob- son et al., 1982; Miranda \& Pelissier, 1981). The capacity for $\alpha$-La digestion in the small intestine also seemed very large, whereas, $\beta$ - $\mathrm{Lg}$ appeared the most resistant to luminal digestion (Fushiki et al., 1986;

Table II. Transepithelial passage of $\beta$-Lg, $\alpha$-La and $\beta$-cas in rabbit ileum mounted in an Ussing chamber in vitro.

\begin{tabular}{lccc}
$\begin{array}{l}\text { Rate of serosal } \\
\text { accumulation } \\
\left(\mu g . h^{-1} . \mathrm{cm}^{-2}\right)\end{array}$ & $\beta$-Lg & $\alpha$-La & $\beta$-cas \\
\hline $\begin{array}{l}{ }^{14} \text { C-protein } \\
\text { equivalents }\end{array}$ & $6.06 \pm 1.14$ & $1.92 \pm 0.10^{*}$ & $1.89 \pm 0.21^{*}$ \\
$\begin{array}{l}\text { Antigenics } \\
\text { proteins }\end{array}$ & $0.41 \pm 0.03$ & $0.13 \pm 0.01^{*}$ & not detectable \\
\hline
\end{tabular}

Values are means $\pm S E$ for 8 animals. Values are calculated from the linear part of the time-dependant serosal accumulation curves of ${ }^{14} \mathrm{C}$-protein equivalents (Fig. 2) and antigenic proteins (Fig. 3 ) in the 70-140 min period of incubation of the ${ }^{14} \mathrm{C}$-radiolabelled proteins $(1 \mathrm{mg} / \mathrm{ml})$ on the mucosal side of isolated rabbit ileum. " significantly different from $\beta$-Lg, $P<0.05$. 
Moritz et al., 1987; Miranda \& Pelissier, 1983). The present results confirm that $\beta-\mathrm{Lg}$ antigens are the most resistant to degradation by proteolytic enzymes. This lower degradability of $\beta-\mathrm{Lg}$ is probably linked to the structure of the protein which makes it less accessible to enzymes.

A main point of interest in this study is the evaluation of the intestinal permeability of milk proteins in vitro. Previous studies have established that proteins can be absorbed by the intestine and that the first stage is endocytotic uptake at the luminal membrane (Cornell et al., 1971; Walker et al., 1972). In the present study, this total uptake, evaluated as radiolabelled-protein equivalent transfer, exhibited differential kinetics for $\beta-\mathrm{Lg}$, in comparison to $\alpha$-La and $\beta$-cas. This result suggests a differential uptake mechanism for $\beta-\mathrm{Lg}$, which remains to be elucidated. After internalization, the main fraction was degraded through the lysomal system, but another small fraction escapes this degradation and is found intact after crossing the mucosa (Heyman et al., 1982; Stern \& Walker, 1984). In the present work, this intact antigenic fraction, measured by ELISA, was also different for the three proteins since none were detected for $\beta$-cas, but significant amounts were found for $\beta-\mathrm{Lg}$ and $\alpha$-La. This result suggests that the resistance of these proteins to intracellular degradation is also differential.

In conclusion, the present results indicate that resistance to proteolytic enzymes, uptake at the luminal membrane, and probably intracellular processing of the milk proteins tested, were differential. In every case $\beta-L g$, antigens appeared to be the most resistant to degradation and the best able to cross the intestinal mucosa. These observations coincide with the idea that $\beta-\mathrm{Lg}$ is the main factor responsible for milk protein sensitization via the oral route (Huang et al., 1985; Koritz et al.,
1987). Further studies are required to determine the mechanism that controls this intestinal permeability to food protein antigens.

\section{REFERENCES}

Baird A.W., Barclay W.S., Balzer-Yost B.L. \& Cuthbert A.W. (1987) Affinity purified immunoglobulin $G$ transfers immediate hypersensitivity to Guinea pig colonic epithelium in vitro. Gastroenterology 92, 635-642

Changin G., Pattern R., Verkasalo J., Kuitinen P. \& Avilathi E. (1981) Cow's milk intolerance. Acta Pediat. Scandinavia 10, 31-35

Cornell R., Walker W.A. \& Isselbacher K.J. (1971) Small intestinal absorption of horseradish peroxidase : a cytochemical study. Lab. Invest. $25,42-48$

Fällström S.P., Ahlstedt S., Carlson B., Wettergren B. \& Hanson I.A. (1984) Influence of breast feeding on the development of cow's milk proteins antibodies and the $\mathrm{lgE}$ level. Int. Archs. Allergy Appl. Immun. 75, 87-91

Fushiki T., Yamamoto N., Naeshiro I. \& Iwai K. (1986) Digestion of $\alpha$-Lactalbumin in rat gastrointestinal tracts. Agric. Biol. Chem. 50, 95-100

Heyman M., Ducroc R., Desjeux J.F. \& Morgat J.L. (1982) Horseradish peroxidase transport across adult rabbit jejunum in vitro. Am. J. Physiol. 242 (Gastrointest. Liver Physiol. 16), G558G564

Huang Q., Coleman J.W. \& Stanworth D. (1985) Investigation of the allergenicity of $\beta$ Lactoglobulin and its cleavage fragments. Int. Archs. Allergy Appl. Immun. 78, 337-344

Jakobson I., Lindberg T. \& Enedikson B. (1982) In vitro digestion of cow's milk proteins by duodenal juice from infants with various gastrointestinal disorders. J. Pediatr. Gastroenterol. Nutr. 1, 183-191

Jentoft N. \& Dearborn D.G. (1979) Labelling of proteins by reductive methylation using sodium cyanoborohydride. J. Biol. Chem. 254, 43594365 
Koritz T.N., Suzuki S. \& Coombs R.R.A. (1987) Antigenic stimulation with proteins of cow's milk via the oral route in Guinea pigs and rats. I. Measurement of antigenically intact $\beta$-Lactoglobulin and casein in the gastrointestinal contents of duodenum, jejunum and ileum. Int. Archs. Allergy Appl. Immun. 82, 72-75

Mercier J.C., Maubois S.L., Poznanski B. \& Ribadeau-Dumas B. (1968) Fractionnement préparatif des caséines de vache et de brebis par chromatographie sur DEAE-Cellulose en milieu urée et 2-mercaptoéthanol. Bull. Soc. Chim. Biol. 50, 521-530

Miranda G. \& Pelissier J.P. (1981) In vivo studies on the digestion of bovine caseins in the rat stomach. J. Dairy Res. 48, 319-326

Miranda G. \& Pelissier J.P. (1983) Kinetic study of in vivo digestion of bovine unheated skim-milk proteins in the rat stomach. J. Dairy Res. 50, 2736

Patrick M.K. \& Gall D.G. (1988) Protein intolerance and immunocyte and enterocyte interaction. Pediatric. Clin. North Am. 35, 17-34

Pearson J.P., Kingston D. \& Shiner M. (1983) Antibody production to milk proteins in the jeju- nal mucosa of children with cow's milk protein intolerance. Pediat. Res. 17, 406-412

Powell D.W., Binder H.J. \& Curran P.F. (1972) Electrolyte secretion by the guinea pig ileum in vitro. Am. J. Physiol. 223, (Gastrointest. Liver Physiol. 16), G531-G537

Reimerdes E.H. \& Klostermeyer H. (1976) Determination of proteolytic activities on casein substrate. In : Methods in Enzymology, vol. XLV, Proteolytic enzymology Part B (Lorand L., ed.) Academic Press, New York, pp. 26-28

Stern M. \& Walker W.A. (1984) Food proteins and gut mucosal barrier. I. Binding and uptake of cow's milk proteins by adult rat jejunum in vitro. Am. J. Physiol. 246 (Gastrointest. Liver Physiol. 16), G556-G562

Suzuki S., Koritz T.N. \& Coombs R.R.A. (1987) Antigenic stimulation with proteins of cow's milk via the oral route in Guinea pigs and rats. II. Antibodies to $\beta$-Lactoglobulin secreted into the alimentary canal and serum. Int. Archs. Allergy Appl. Immun. 82, 76-82

Walker W.A., Cornell R., Davenport I.M. \& Isselbacher K.T. (1972) Macromolecular absorption : mechanism of horseradish peroxidase uptake in adult and neonatal rat intestine. J. Cell. Biol. 54, 195-205 